\title{
硬化セメントペーストのスケーリング劣化に及ぼす塩化物の影響 \\ INFLUENCE OF CHLORIDES ON SCALING DETERIORATION OF HARDENED CEMENT PASTES
}

\author{
藤井卓*.藤田嘉夫** \\ By Takashi FUJII and Yoshio FUJITA
}

\begin{abstract}
This paper describes the scaling of hardened cement pastes subjected to freezing and thawing in salt solutions such as $\mathrm{NaCl}, \mathrm{CaCl}_{2}, \mathrm{MgCl}_{2}$ and sea water. The various factors affecting to scaling such as salt solution, concentration, drying and air entraining were investigated in connection with the microstructural features. The severest scaling was observed on the non $\mathrm{AE}$ pastes in $\mathrm{NaCl}, \mathrm{CaCl}_{2}$ solutions and sea water caused by the damage of $\mathrm{Ca}(\mathrm{OH})_{2}$ and the collapse of $\mathrm{CSH}$. The rate of scaling decreases with freeze-thaw cycle on the non $\mathrm{AE}$ paste in $\mathrm{MgCl}_{2}$ solution and on the $\mathrm{AE}$ paste in $\mathrm{CaCl}_{2}$ solution and sea water due to the dense layer formed near the surface. However very porous portion was observed at adjacent to the dense layer. The cavities in dried $\mathrm{AE}$ paste are filled with new compounds and the shell of air voids becomes denser and thicker. Consequently the dried $\mathrm{AE}$ paste is much more resistant to surface scaling than non dried one.
\end{abstract}

\section{1. まえがき}

寒冷地におけるコンクリートが, 融水塩あるいは海水 などの作用を受ける場合は，塩化物および海水成分の化 学作用と凍結融解の物理作用を同時に受けるため, その 劣化の著しいことが知られている.このようなコンク リートの劣化には, マトリックスとしての硬化セメント ペーストの劣化特性が, 大きな影響を与える. 硬化セメ ントペーストが融氷塩あるいは海水の作用を受ける場合 は, 水和反応の結果生成した各種の水和物と塩化物ある いは海水成分との化学反応により微構造に変化を生じ, さらに空隙水の凍結融解により水和物が損傷を受け組織 が弛緩する.このように塩分環境におけるコンクリート の凍結融解劣化は, 硬化セメントペースト微構造の化学 的, 物理的変化に起因しており, この劣化機構を解明す るためには, マクロな劣化現象と微構造変化との関連を 明らかにすることが必要と考えられる.

塩化物と凍結融解の繰返し作用を受けるコンクリート 系材料の劣化に関しては主としてマクロな研究がなさ

* 正会員 工博 函館工業高等専門学校教授 土木工学科 ( ( 042 函館市户倉町 226)

** 正会員 工博 北海道大学教授 工学部土木工学科 ( ₹060 札愰市北区北 13 条西 8 )
れ, 国外では融水塩と凍結融解作用によるコンクリート 舗装, 橋床版のスケーリング劣化を扱った研究が多く, 有名なVerbeck, Klieger ${ }^{11}$ の研究があり,さらに Hartmann ${ }^{21}$, Cordon ${ }^{31}$, Browne ら"1などの成果がある. また，わが国では前川ら ${ }^{51}$, 佐伯, 鮎田ら ${ }^{6171}$ による海水 と凍結融解作用を受ける海岸コンクリートのスケーリン グ劣化に関する研究成果が多数ある. 一方, ミクロなア プローチのうち走査型電子顕微鏡による微構造を扱った 研究としては, 塩溶液がカルシウムシリケート水和物 (CSH) の結合物質を損傷することを指摘した Hochstetter ${ }^{8)}$ の成果, および塩化物が作用する場合では ないが, 凍結融解作用を受けた若材令の硬化セメント ペーストの微構造を観察し, $\mathrm{Ca}(\mathrm{OH})_{2}$ および空隙の変 化が凍結融解劣化に関与することを示唆した Kayyali らの研究"'がみられる程度である.

著者らは, $\mathrm{MgCl}_{2}$ 溶液中で凍結融解作用を受ける硬 化セメントペーストの劣化に関してすでに報告してい $3^{(0)}$ が, 本研究は塩分環境におけるコンクリートの凍結 融解作用によるスケーリング劣化機構を解明するための 研究の一環として, スケーリング劣化を微構造変化およ び水和物の化学的変化との関連において検討したもので ある.すなわち, $\mathrm{NaCl}, \mathrm{CaCl}_{2}, \mathrm{MgCl}_{2}$ などの融水塩 および海水を取り上げ，マトリックスとしての硬化セメ 
ントペーストを対象に，スケーリング劣化に与える塩溶 液の種類および濃度, 前処理乾燥, エントレインドエア一 などの影響を，走査型電子顕微鏡（SEM）による微構 造変化の視覚的観察, エネルギ分散型 $\mathrm{X}$ 線マイクロア ナライザ (EDXA)，X 線回折 (XRD) および示差熱分 析（DTA）などによる元素分析, 生成物の同定, 定量 の結果との関連において検討している.

\section{2. 実験方法}

実験の概要をTable 1 に, 実験に用いた普通ポルトラ ンドセメントの諸性質を Table 2 に示す。ペーストの配 合は初期固相率 $V_{s 0}{ }^{101} 40 \%$ (W/C $56 \%$ )とした.ただ， $\mathrm{Mg} \mathrm{Cl}_{2} 3 \%$ 溶液のみについては初期固相率 $35,45 \%$ (W/C 70，45\%) についても実施した．AEペースト では空気量 $4 \%$ を目標に，ヴィンソルをセメント質量 の $0.03 \%$ 混入した。供試体寸法は $40 \times 40 \times 160 \mathrm{~mm}$ と し，養生程度は積算温度 $210^{\circ} \mathrm{DD}$ となるよう鋼製 3 連型 枠に型詰めし，ガラス板で覆って 24 時間 $20^{\circ} \mathrm{C}$ で湿空 養生した後, 脱型した供試体を材令 7 日まで $20^{\circ} \mathrm{C} \pm$ $1^{\circ} \mathrm{C}$ の水中で養生した。 なお，ブリージングにより多孔 化した供試体の上表面は特別な処理はしていない。実験 1 では所要の積算温度を得た供試体を, $\mathrm{NaCl} 3 \%$, $\mathrm{CaCl}_{2} 3,6,10,20 \%, \mathrm{Mg} \mathrm{Cl}_{2} 3,6,10,20 \%$ の 各溶液, 海水掞よび真水中で，また実験 2 では養生後 $30^{\circ} \mathrm{C}, 65$ $\% \mathrm{RH}$ で 3 日間乾燥した供試体を, $\mathrm{NaCl} 3 \%, \mathrm{CaCl}_{2}$ $3,6,10,20 \%, \mathrm{Mg} \mathrm{Cl}_{2} 3,6 \%$ 溶液, 海水および真水中 で涷結融解試験を行った。冷却最低温度を $-20^{\circ} \mathrm{C}$, 加 熱最高温度を $+5^{\circ} \mathrm{C}, 12$ 時間を $1 \mathrm{cyc}$. として凍結融解 を繰り返した.所定のサイクルごとに損失質量を測定し， スケーリング破面および曲げ破面（供試体製作時の上表 面である引張縁端を含む約 $10 \mathrm{~mm}$ ) から試料を採取し 微構造の変化状態を走査型電子影微鏡 (SEM) により 観察し，X 線回折 (XRD)，示差熱分析 (DTA) お上 びX 線マイクロアナライザ (EDXA) による各種分析 を行った。

DTA およびEDXAの一部では供試体をアセトン中 においてメノウ乳鉢により粉砕した後，D-dry 法により 24 時間乾燥して分析試料とした. EDXA 用の他の供試
Table 2 Properties of cement

\begin{tabular}{|c|c|c|c|c|c|c|c|c|c|}
\hline \multirow[b]{2}{*}{ ig.10ss } & \multicolumn{9}{|c|}{ Chemical composition } \\
\hline & sinsol & $5 \mathrm{SiO}_{2}$ & $\mathrm{Al}_{2} \mathrm{O}_{3}$ & \begin{tabular}{|l|l|}
3 & $\mathrm{Fe}_{2}$ \\
\end{tabular} & \begin{tabular}{l|l}
$0^{0}$ & $\mathrm{Ca}_{2}$ \\
\end{tabular} & \begin{tabular}{l|l}
$\mathrm{CaO}$ & $\mathrm{M}$ \\
\end{tabular} & \begin{tabular}{|l|l|}
$\mathrm{MgO} \mathrm{SO}_{3}$ \\
\end{tabular} & 合到 & f.CaO \\
\hline 0.4 & 0.1 & 22.6 & 4.9 & & $1 . 8 \longdiv { 6 4 }$ & \begin{tabular}{l|l}
64.5 & 1 \\
\end{tabular} & \begin{tabular}{|l|l|}
1.6 & 2.0 \\
\end{tabular} & 98.9 & 0.3 \\
\hline \multicolumn{10}{|c|}{ Compound composition \% } \\
\hline & & $\mathrm{C}_{3} \mathrm{~S}$ & $\mathrm{C}_{2} \mathrm{~S}$ & $\mathrm{C}_{3} \mathrm{~A}$ & \multicolumn{2}{|c|}{\begin{tabular}{|l|l|l|}
$C_{4} A F$ & $C S$ \\
\end{tabular}} & 5 & & \\
\hline & & 48 & 29 & 8 & 8 & 3 & 3 & & \\
\hline \multicolumn{10}{|c|}{ Physical properties } \\
\hline \multirow{2}{*}{$\begin{array}{l}\text { ecifict } \\
\text { avity }\end{array}$} & Finess: & $\begin{array}{l}\text { Settrt } \\
\text { time- } \\
\text { time }\end{array}$ & & $\begin{array}{l}\text { Fexur } \\
\text { sereng } \\
\text { reng }\end{array}$ & $\begin{array}{ll}\mathrm{rat} \\
\mathrm{gth}:\end{array}$ & $\mathrm{MPa}$ & $\begin{array}{l}\text { Compres } \\
\text { streng } \\
\text { stren }\end{array}$ & 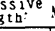 & $\mathrm{MPa}$ \\
\hline & $\mathrm{cm}^{2} / \mathrm{s}$ & init.ff & final & $3000 y_{3}$ & $7+509$ & $288^{2 x y}$ & 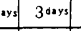 & $700 \times 3$ & 28 days \\
\hline 3.16 & 3100 & \begin{tabular}{l|l}
$3-05$ & 4 \\
\end{tabular} & $4-10$ & 3.0 & 4.3 & 6.6 & \begin{tabular}{|l|l|l|} 
& 12.7 & 2 \\
\end{tabular} & 22.2 & 39.5 \\
\hline
\end{tabular}

体では，曲げ引張破面のうち引張縁端（作製時および浸 漬時の上面側）から $10 \mathrm{~mm}$ の部分を採取してアセトン 中に 24 時間浸漬し水和を停止した後, 48 時間 D-dry 法 で乾燥した試料を $\mathrm{Au}$ コーティングして用いた．X線回 折 (XRD) 装置は, 理学電機のガイガーフレックス 213 によった.測定条件は, 電圧 : $30 \mathrm{kVP}$, 電流：20 mA, カウントフルスケール：1000 cps とした。示差熱分析 （DTA）は，島津製作所の DT-30 システムにより行っ た. 試料質量を $20 \mathrm{mg}$ とし基準物質には $\alpha$ アルミナ 20 $\mathrm{mg}$ を用いた。加熱速度を $20^{\circ} \mathrm{C} / \mathrm{min}$ として, 室温から $850 \sim 900^{\circ} \mathrm{C}$ まで昇温した。X線マイクロアナライザ

(EDXA) は, 走査型電子影微境 (日本電子, JSM-25 SIII) 付属のエネルギ分散型（KEVEX，7100/15）を 用い, 加速電圧 $250 \mathrm{kV}$, 試料電流を粉末試料では 1.4 $\times 10^{-9} \mathrm{~A}$ ，破面試料では $0.5 \times 10^{-9} \mathrm{~A}$ に設定し，分析時 間を $300 \mathrm{~s}$ とした.

\section{3. スケーリング劣化に及ぼす塩溶液の種類の 影響}

\section{（1） 水和物の化学的变化}

各種塩溶液中で涷結融解を繰り返した硬化セメント ペーストのX 線回折 (XRD) 結果をFig.1に示す.こ れは塩溶液の種類および涷結融解回数による相違をみた ものであるが，比較のため真水中で $210^{\circ} \mathrm{DD}$ を得た凍結 融解以前の供試体の分析結果も示した. 凍結融解 $6 \mathrm{cyc}$. における $\mathrm{NaCl}, \mathrm{CaCl}_{2} 3$ \% 溶液および海水浸漬の場合 のXRD パターンはほぼ等しい，また，すでにこの段階 でフリーデル塩 $\left(3 \mathrm{CaO} \cdot \mathrm{Al}_{2} \mathrm{O}_{3} \cdot \mathrm{CaCl}_{2} \cdot 10 \mathrm{H}_{2} \mathrm{O}\right)$ が生成 しているのが認められる．塩溶液中で涷結融解作用を受

Table 1 Outline of experiments.

\begin{tabular}{|c|c|c|c|c|c|c|c|c|}
\hline \multirow{2}{*}{ No. } & \multicolumn{3}{|c|}{ Specimen } & \multicolumn{5}{|c|}{ Test } \\
\hline & $\begin{array}{l}\text { Initial solid phase } \\
V_{\text {So }}(\mathbb{W} / \mathrm{C}) \%\end{array}$ & $\mathrm{AE}$ & Curing $^{\circ} \mathrm{DD}$ & Drying & Solution & Temperature ${ }^{\circ} \mathrm{C}$ & Duration & Measuring iten \\
\hline 1 & $\begin{array}{c}35,40,45 \\
(70,56,45)\end{array}$ & $\begin{array}{l}\text { Non }(\mathrm{N}) \\
\operatorname{AE}(\mathrm{A})\end{array}$ & 210 & Non & $\begin{array}{l}\text { lire }(\text { (W) } \text {, sea }(\mathrm{S}), \mathrm{NaCl} 3 \%(\mathrm{~N} 3) \\
\text { water } \\
\mathrm{CaCl}_{2} 3,6,10,20 \%(\mathrm{C} 3 \sim \mathrm{C} 20) \\
\mathrm{MgCl}_{2} 3,6,10,20 \% \text { (M3 M20) }\end{array}$ & $+5 \sim-20$ & $\begin{array}{l}24 \mathrm{cyc} . \\
36 \mathrm{cyc} .\end{array}$ & $\begin{array}{l}\text { Weight loss, SEM, EDXA, } \\
\text { XRD , DTA }\end{array}$ \\
\hline 2 & $\begin{array}{c}35,40,45 \\
(70,56,45)\end{array}$ & Non (N) & 210 & Dry (I) & $\begin{array}{l}\text { Fresh (W), Sea (S), } \mathrm{NaCl} 3 \%(\mathrm{~N} 3) \\
\text { vater } \\
\mathrm{CaCl}_{2} 3,6,10,20 \%(\mathrm{C3} \sim \mathrm{C} 20) \\
\mathrm{MgCl}_{2}{ }^{3}, 6 \%(\mathrm{M} 3, \mathrm{M} 6)\end{array}$ & $+5 \sim-20$ & $\begin{array}{l}24 \mathrm{cyc} \text {. } \\
36 \mathrm{cyc} \text {. }\end{array}$ & $\begin{array}{l}\text { weight loss, SEM, EDXA, } \\
\text { XRD, DTA }\end{array}$ \\
\hline
\end{tabular}

Remark $1 . V_{50} 35,45 \%$ and duration 36 cycles rere performed for only $\mathrm{MgCl}_{2}$ solution.

2.The sark for specinen is $A+B$ or $A+B+C$ in which $A, B$ and $C$ indicate solution $(S, N 3$ etc.), AE (Non : $N, A E: A)$ and $F-T$ cycles $(6,24$ etc.) respectively. 
ける場合は， $\mathrm{Cl}^{-}$イオンの浸入による $\mathrm{Ca}(\mathrm{OH})_{2}$ の溶出 にもかかわらず, $\mathrm{Ca}(\mathrm{OH})_{2}$ のピーク強度は真水中の場 合よりもやや強く, 凍結融解作用を受けながらも 6 cyc. までは水和反応が徐々に進行することを示す。 $\mathrm{Ca} \mathrm{Cl}_{2} 3$ \% 溶液浸漬の場合の $24 \mathrm{cyc}$. での XRD パターンは, 6 cyc.のときとあまり相違はないが, 24 cyc.の方がフリー

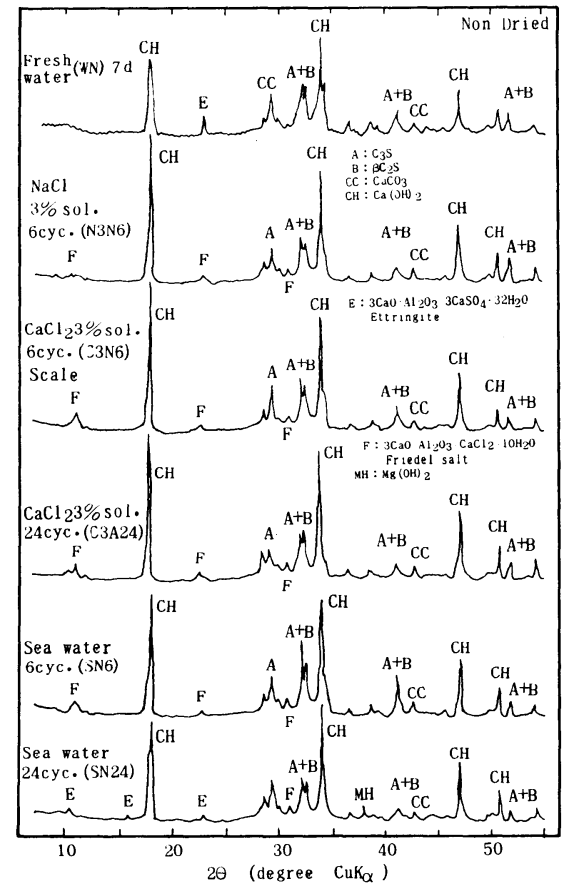

Fig. 1 Change of hydrates due to F-T in salt solutions (XRD).

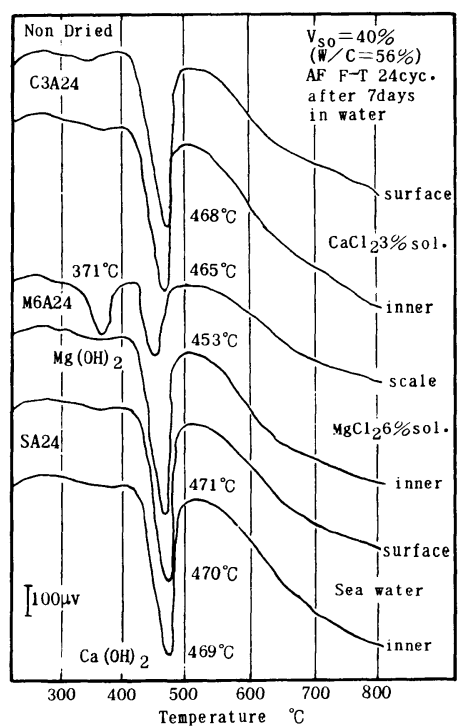

Fig. 2 Difference of compound between surface and inner portion (DTA).
デル塩のピークがやや強いのが認められる，海水浸漬の 場合は, $24 \mathrm{cyc}$. では $\mathrm{Ca}(\mathrm{OH})_{2}$ のピークも弱くなり, $\mathrm{Mg}(\mathrm{OH})_{2}$ のピークが明瞭に現われる.また，フリーデ ル塩の他にエトリンガイト $\left(3 \mathrm{CaO} \cdot \mathrm{Al}_{2} \mathrm{O}_{3} \cdot 3 \mathrm{CaSO}_{4} \cdot 32\right.$ $\left.\mathrm{H}_{2} \mathrm{O}\right)$ の生成が認められる.この場合のエトリンガイト は, セメント水和物である $\mathrm{Ca}(\mathrm{OH})_{2}$ とモノサルフェー 卜 $\left(3 \mathrm{CaO} \cdot \mathrm{Al}_{2} \mathrm{O}_{3} \cdot \mathrm{CaSO}_{4} \cdot 12 \mathrm{H}_{2} \mathrm{O}\right)$ に海水中の $\mathrm{MgSO}_{4}$ が作用して二次生成したものと考えられる.

Fig. 2 はDTAの結果であり, 塩溶液中で涷結融解を 24 cyc. 行った場合の表層部あるいはスケールと内部と の相違を示したものである. いずれの場合も 453〜471 ${ }^{\circ} \mathrm{C}$ の範囲に $\mathrm{Ca}(\mathrm{OH})_{2}$ の吸熱ピークがみられる. $\mathrm{CaCl}_{2}$ 溶液浸漬では表層部と内部で DTA 曲線は類似してお り，特に差異は認められない。 $\mathrm{MgCl}_{2}$ 溶液浸漬の場合 のスケールでは $\mathrm{Ca}(\mathrm{OH})_{2}$ のピークも小さく，またス ケールのみに $371^{\circ} \mathrm{C} に \mathrm{Mg}(\mathrm{OH})_{2}$ の吸熱ピークがある が，内部ではほとんど認められない。これは $\mathrm{MgCl}_{2}$ 溶 液浸漬では表層部に $\mathrm{Mg}(\mathrm{OH})_{2}$ の緻密層が形成された後 は $\mathrm{Mg}^{2+}$ イオンの内部への浸入はあまり生じないことを 示す.

\section{（2）塩溶液の種類による相違}

ブリージングの影響を受けて表層部が多孔化した硬化 セメントペーストが，塩溶液中で涷結融解作用を受けた 場合のスケーリング劣化パターンは, $V_{s 0}$, 冷却最低温 度などにより相違することはすでに知られている ${ }^{101}$. 塩 溶液の種類によるスケーリングの相違（Fig. 3）は，そ の劣化パターンを大別して 4 つに分けて記述することが できる. Non $\mathrm{AE}$ の $\mathrm{NaCl}, \mathrm{CaCl}_{2}$ 溶液, 海水浸漬の場 合は凍結融解サイクルの比較的早い時点における吸水後 に急激に劣化し，次に $\mathrm{AE} の \mathrm{NaCl}$ および $\mathrm{CaCl}_{2}$ 溶液 浸漬の場合は, きわめて早期に比較的急速に劣化し, そ の後やや劣化を緩めながらも早い速度で劣化する.さら にNon $\mathrm{AE}$ の $\mathrm{MgCl}_{2}$ 溶液, 真水および $\mathrm{AE}$ の $\mathrm{MgCl}_{2}$

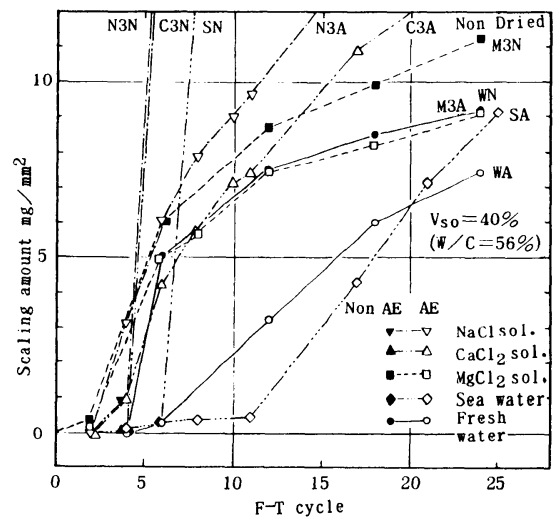

Fig. 3 F-T cycle $\sim$ scaling amount relationship (Difference due to chlorides). 


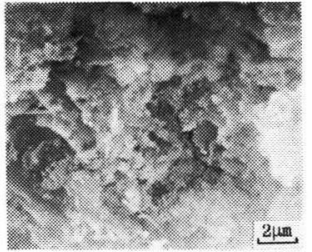

Photo 1 Collapse of $\mathrm{CSH}$ at surface portion in $\mathrm{NaCl} 3 \%$ sol.

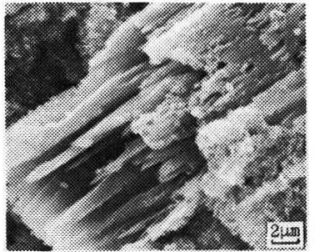

Photo 2 Damage of $\mathrm{Ca}(\mathrm{OH})_{2}$ at surface portion in $\mathrm{CaCl}_{2} 3 \%$ sol.

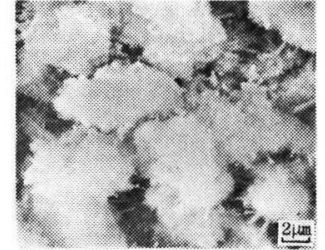

Photo 3 Disintegration of CSH at surface portion in sea water.

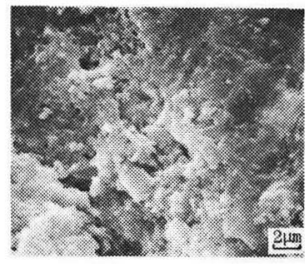

(a) Dense morphology of surface portion.

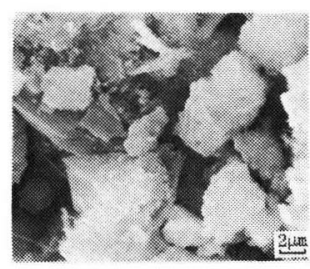

(b) Porous state at around $1 \mathrm{~mm}$ from surface.
Photo $4 \mathrm{CaCl}_{2} 3 \%$ solution.

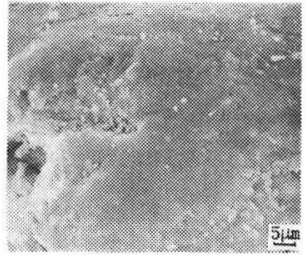

(a) Dense state at surface portion

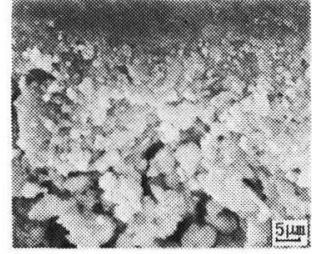

(b) Porous portion adjacent to dense layer.
Photo $5 \mathrm{MgCl}_{2} 3 \%$ solution

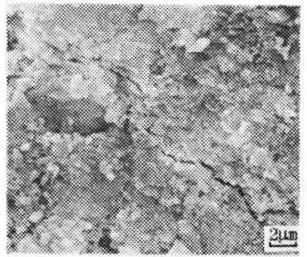

(a) Dense state at surface portion

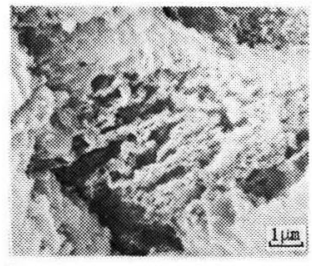

(b) Damage of $\mathrm{CSH}, \mathrm{Ca}(\mathrm{OH})$ at inner portion
Photo 6 Sea water.

溶液浸漬の場合は, 早期には比較的急速に劣化しながら もその後緩やかに劣化が進行する. また， AEの真水， 海水の場合は初期の劣化が小さく，その後の劣化はほぼ 一定の勾配で進行する.

Non $\mathrm{AE} の \mathrm{NaCl}, \mathrm{CaCl}_{2}$ 溶液浸漬の場合は, 4 cyc. から急激に劣化し $8 \mathrm{cyc}$. で崩壊し, Non AE の海水浸 漬の場合は 6 cyc. から急激に劣化し 10 cyc. で崩壊し た. $\mathrm{NaCl}$ 溶液浸漬の場合の表層付近の微構造はきわめ て多孔的であり，多数のエトリンガイトが認められ，表 層内側 1 2 mm の CSH も損傷しており (Photo 1), 表 層部および内部 $(8 \sim 10 \mathrm{~mm})$ においても $\mathrm{Ca}(\mathrm{OH})_{2}$ が著
しく崩壊しているのが観察された。 $\mathrm{CaCl}_{2}$ 溶液浸漬の場 合は, 表層内側 $(1 \sim 2 \mathrm{~mm})$ の形態は $\mathrm{Ca}(\mathrm{OH})_{2}$ が比較 的健全なものと損傷したものが混在し (Photo 2), $\mathrm{NaCl}$ 溶液浸漬の場合に認められたエトリンガイトがほ とんど観察されない.内部では $\mathrm{NaCl}$ 溶液浸漬の場合と 同様に $\mathrm{Ca}(\mathrm{OH})_{2}$ が層状に剝離し溶出しており, $\mathrm{CSH}$ の崩壊も観察された. Non AE の海水の場合, 表層部の 微構造形態はPhoto 3 に示すように多孔的で未発達な $\mathrm{CSH}$ （I）の分離が観察され，CSH（III）の崩壊および $\mathrm{Ca}(\mathrm{OH})_{2}$ の損傷が認められた。内部では多数の $\mathrm{Ca}$ $(\mathrm{OH})_{2}$ の損傷および CSH（III）の粒状の分離崩壊が観 察された.

$\mathrm{AE}$ の NaCl, $\mathrm{CaCl}_{2}$ 溶液の場合は, 2 cyc. から急激 に劣化し始め 6 cyc. 以降では劣化の割合を緩めながら も急速に劣化し， $\mathrm{NaCl}$ 溶液の場合は $22 \mathrm{cyc}$.で，また $\mathrm{CaCl}_{2}$ 溶液の場合は $24 \mathrm{cyc}$. で崩壊した. $\mathrm{CaCl}_{2}$ 溶液の 場合の断面の微構造をみると, 表面には緻密な部分があ り，表層内側 $1 \mathrm{~mm}$ 以内は健全な形態 (Photo 4(a)) を 示すが，その直下には著しく多孔化した部分（Photo 4 (b)）が観察された。 スケール上面には角柱状の結晶が 多数密生しており, スケール破面の端部にも同様の結晶 が折損した形態で多数認められる. また，スケール破面 の中央部は比較的緻密な形態を示し, さらに空隙中には 粒状物質を生成しているのが観察された.

$\mathrm{MgCl}_{2}$ 溶液では Non $\mathrm{AE}, \mathrm{AE}$ ともに 2 cyc. から劣 化を開始し, 6 cyc. 以降は劣化勾配が徐々に低減し，そ の後 24 cyc. においても残存断面は健全であった. また， Non AE の真水の場合は, 4 cyc. から劣化を開始し, $\mathrm{AE} の \mathrm{MgCl}_{2}$ 溶液の場合とほぼ同様に, 6 cyc. 以降の 劣化勾配は徐々に低下した。このパターンの場合, $\mathrm{MgCl}_{2}$ 溶液では表面付近に $\mathrm{Mg}(\mathrm{OH})_{2}$ の緻密層(Photo 5 (a)）を形成し，その直下に著しい多孔部 (Photo5(b)) が認められる.真水の場合にはこうした形態は生じない. また，スケール破面の微構造は，端部に緻密組織がみら れ，中央部には小型粒状の生成物が多数認められるが, 真水中の場合はこうした形態は観察されない.

$\mathrm{AE}$ の真水の場合は 4 cyc. から劣化が始まり, 比較的 緩い勾配でスケーリングがほぼ直線的に増大し， 24 cyc. まで比較的健全であった， AE の海水の場合は 11 
cyc. 程度まで劣化は比較的緩慢に進行し，それ以後は 真水の場合より若干急な勾配でほぼ直線的に劣化が増大 し, 24 cyc. で Non $\mathrm{AE}$ の真水および $\mathrm{AE} の \mathrm{MgCl}_{2}$ 溶 液の場合とほぼ同じ劣化状態となった。 $\mathrm{AE}$ の海水の場 合の微構造は, Photo 6 に示すように表面付近が部分的 に緻密化し，全体的に多孔的な部分が多いが，内部にお いても $\mathrm{CSH}$ および $\mathrm{Ca}(\mathrm{OH})_{2}$ が損傷し組織が弛緩して いる.

\section{4. スケーリング劣化に及ぼす塩溶液の濃度の 影響}

\section{（1） 水和物の化学的変化}

凍結融解 $24 \mathrm{cyc}$.におけるスケールと内部および塩溶 液濃度による水和物の相違を Fig. 4 に示す。 $\mathrm{CaCl}_{2} 6 \%$ 溶液浸漬の場合のスケールは，内部に比較して Ca $(\mathrm{OH})_{2}$ のピークが弱く, フリーデル塩のピークが強く なる. $\mathrm{CaCl}_{2} 10 \%$ 溶液浸漬の場合のスケールは, フリー デル塩のピーク強度は他のスケールの場合と同程度であ るが, $\mathrm{Ca}(\mathrm{OH})_{2}$ のピークは逆に強くなっており，

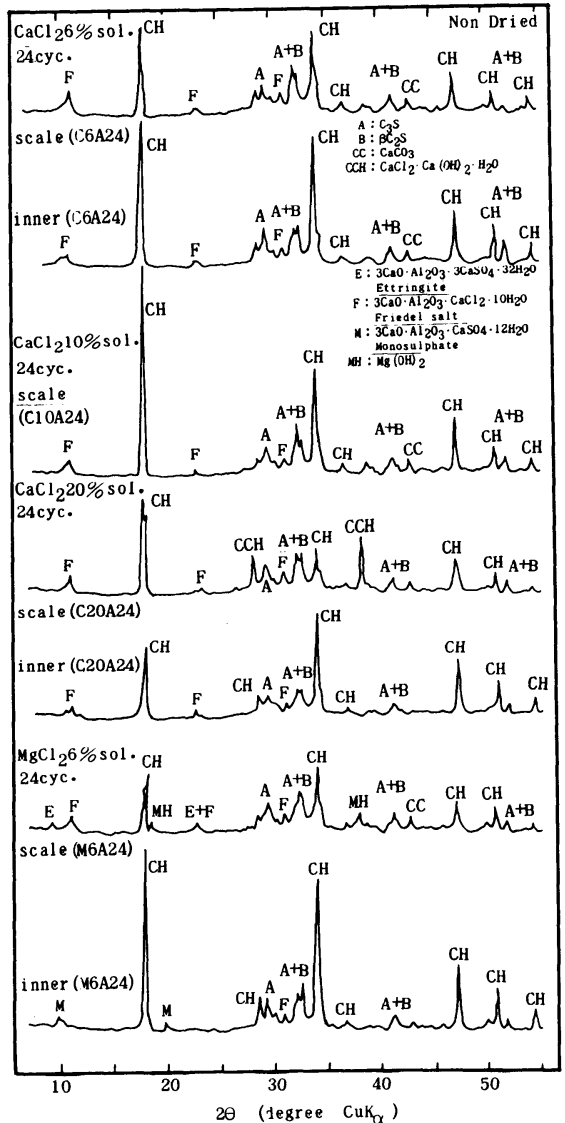

Fig. 4 Difference of compound between scale and inner portion.
$\mathrm{CaCl}_{2} 10 \%$ 溶液浸漬では他と異なって表層付近に $\mathrm{Ca}$ $(\mathrm{OH})_{2}$ が新たに生成されることを示す. $\mathrm{CaCl}_{2} 20 \%$ 溶 液浸漬の場合は，6\%溶液の場合と同様にスケールにお いて $\mathrm{Ca}(\mathrm{OH})_{2}$ のピーク強度が小さくなり，フリーデル 塩のピークが強くなる。さらに $\mathrm{CaCl}_{2} 20 \%$ 溶液浸漬の 場合のスケールには，全く新しい生成物として $\mathrm{CaCl}_{2} \cdot \mathrm{Ca}(\mathrm{OH})_{2} \cdot \mathrm{H}_{2} \mathrm{O}$ のような複塩を生じた. $\mathrm{MgCl}_{2}$ $6 \%$ 溶液浸漬で 24 cyc. 凍結融解した場合，スケールで は内部に比較して $\mathrm{Ca}(\mathrm{OH})_{2}$ のピーク強度が著しく低下 し，モノサルフェートが消失し，エトリンガイトが現わ れ，フリーデル塩のピークが強くなり，さらに $\mathrm{Mg}$ $(\mathrm{OH})_{2}$ が新たに生成する.

DTAによる測定結果によれば，スケールおよび内部 における $\mathrm{Ca}(\mathrm{OH})_{2}$ のピークが，塩溶液の濃度によって 著しく異なった挙動を示すのが認められる．特に濃度 $20 \%$ の塩溶液の場合のスケールではピーク温度 $560^{\circ} \mathrm{C}$ を有する新しい生成物が認められ， $\mathrm{Ca}(\mathrm{OH})_{2}$ のピーク 温度範囲 $450 \sim 500{ }^{\circ} \mathrm{C}$ より少し低いピーク温度 $439^{\circ} \mathrm{C}$ を有する物質も生成している．スケールと内部の生成物 の相違を Fig. 5 に示す．表層またはスケールにおける $\mathrm{Ca}(\mathrm{OH})_{2}$ 量は，多い方から $\mathrm{CaCl}_{2} 3 \%, 10 \%, 6 \%$ ， $\mathrm{MgCl}_{2} 6 \%, \mathrm{CaCl}_{2} 20 \%$ 溶液の順であり, $\mathrm{CaCl}_{2}$ 溶液 の場合, 濃度により残留 $\mathrm{Ca}(\mathrm{OH})_{2}$ に著しい差異がある. これに対して内部の場合はその差は少ない。これらは $\mathrm{XRD}$ の結果において，スケールの場合の $\mathrm{CaCl}_{2} 6 \%$ で は $\mathrm{Ca}(\mathrm{OH})_{2}$ のピークが弱くなり，10\%ではむしろ $\mathrm{Ca}$ $(\mathrm{OH})_{2}$ のピークが強く, $20 \%$ では $\mathrm{Ca}(\mathrm{OH})_{2}$ のピーク が弱くなり， $\mathrm{Ca}(\mathrm{OH})_{2}$ と複塩をなす新生成物 $\mathrm{CaCl}_{2}$. $\mathrm{Ca}(\mathrm{OH})_{2} \cdot \mathrm{H}_{2} \mathrm{O}$ を生じていることに対応している. また， $\mathrm{MgCl}_{2} 6 \%$ 溶液浸漬でのスケールにおいて $\mathrm{Ca}(\mathrm{OH})_{2}$ が 特に減少するのは, $\mathrm{Mg}^{2+}$ と $\mathrm{Ca}^{2+}$ との置換による $\mathrm{Ca}^{2+}$ の溶出之表面における $\mathrm{Mg}(\mathrm{OH})_{2}$ の析出のためである。

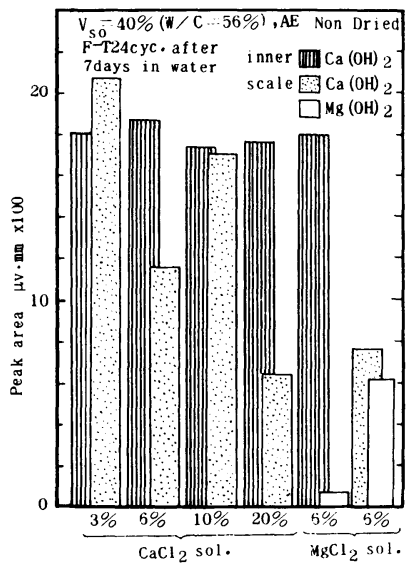

Fig. 5 Comparison of compound at scale and inner portion (DTA). 


\section{（2）塩溶液の濃度による相違}

Fig. 6 に $\mathrm{CaCl}_{2} 3,6,10,20 \%$ 溶液中で涷結融解を繰り 返した場合のスケーリング劣化状況を示す. Non AEの $3,6,10 \%$ 溶液の劣化が最も大きく, 次いで AEの $3,6,10 \%$ の順となっている. 劣化がきわめて小さい 20 \%の場合は, Non AEの方がAEよりやや小さい. Non AEの $3 \%$ 溶液の場合について微構造をみると, 表層部は多孔化し， $\mathrm{Ca}(\mathrm{OH})_{2}$ が損傷しており，内部で は微構造は $\mathrm{CSH}$ が著しく崩壊すると同時に $\mathrm{Ca}(\mathrm{OH})_{2}$ も損傷しているのが観察された。 $\mathrm{AE}$ の $6 \%$ 溶液の場 合，表層 $1.5 \mathrm{~mm}$ までは比較的緻密な形態を示すが，そ の直下は多孔部に移行する. 空隙は新たな生成物で充填 され, 内部 $(6 \sim 8 \mathrm{~mm})$ では比較的空隙の少ない形態が 観察された。スケール破面の端部では緻密な形態を示す が，中間部では CSH を主体とする多孔的な組織で, $\mathrm{Ca}$, $\mathrm{Si}, \mathrm{Cl}$ を主成分元素とする絨維状の物質が生成してい る.また，中央部にはきわめて大型の棒状結晶が密生し， その表面は溶結状態を示す。主な成分元素は $\mathrm{Ca}, \mathrm{Cl}$ で あり, 塩基性塩化カルシウム $\left(3 \mathrm{CaO} \cdot \mathrm{CaCl}_{2} \cdot 15 \mathrm{H}_{2} \mathrm{O}\right)$, または $\mathrm{CaCl}_{2} \cdot \mathrm{Ca}(\mathrm{OH})_{2} \cdot \mathrm{H}_{2} \mathrm{O}$ と $\mathrm{Ca}(\mathrm{OH})_{2}$ の固溶体の可 能性がある。

$\mathrm{AE}$ の $20 \%$ 溶液の場合, 断面全体にわたって空隙中 に, CSH（I）にきわめて類似した針状の新たな生成 物が，空隙を充填するのが観察された。この新生成物の 主成分元素は Caが $78.8 \%$ と多く，これに $\mathrm{Si} ， \mathrm{Cl}$ が それぞれ $10 \%$ である. また，表層付近の破面では，全 面的に六角棒状の大型結晶が密生し，この結晶の主成分 元素は，表層部では $99.5 \%$ が Caであり，これに Cl を $0.5 \%$ 含むが, 内部では $\mathrm{Ca}$ が $100 \%$ であった. また， Non AEの $20 \%$ 溶液の場合も AE の場合と，ほほ同様 の傾向がみられた.

以上の観察から, $20 \%$ 溶液の場合は, 空隙およびマ

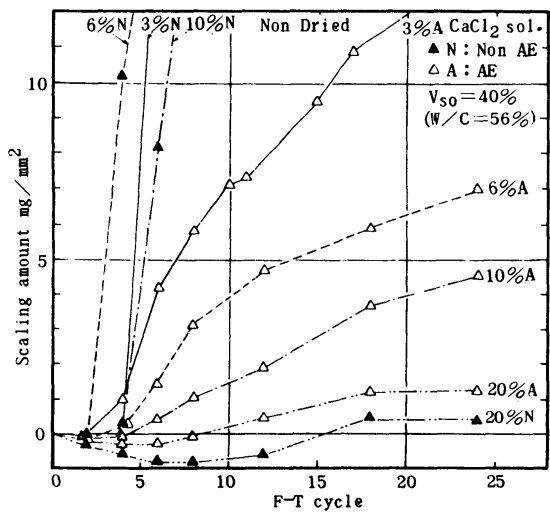

Fig. 6 F-T cycle $\sim$ scaling amount relationship (consentration of $\mathrm{CaCl}_{2}$ sol. ).
イクロクラックなどが新たな生成物によって充填される ため, $\mathrm{Cl}^{-}$インの浸入が抑制され, また溶液の濃度が 高いため凍結温度が低いのが, 劣化を生じない理由と考 えられる.さらに, Non AEでは AEに比べて吸水度が 小さいため劣化が最も小さくなっている。

Fig. 7 に $\mathrm{MgCl}_{2}$ の3,6,10 および $20 \%$ 溶液中で凍結 融解を繰り返した場合のスケーリング劣化状況を示す. Non $\mathrm{AE}$ の $6,10 \%$ の場合の劣化が著しく, $10 \%$ およ び $6 \%$ 溶液の場合がそれぞれ 2 cyc. および 6 cyc. 後, 急激に劣化した。 また， $3 \%$ の場合はNon AE，AEと もに $\mathrm{CaCl}_{2}$ 溶液の場合よりも劣化は小さい。スケーリ ングは 2 cyc. から開始し, サイクルの増加に伴って劣 化の割合が徐々に減少した。この場合の微構造は,

Photo 5(a)に一例を示したように凍結融解の進行に伴っ て表層付近に $\mathrm{Mg}(\mathrm{OH})_{2}, \mathrm{CSH}$ を主成分とする緻密な 組織が形成される.また, $\mathrm{AE}$ の $6 \%$ および $10 \%$ 溶液 の場合も, 同一濃度の $\mathrm{CaCl}_{2}$ 溶液の場合に比較して劣 化は小さく，これは上述と同様に表層付近における $\mathrm{Mg}$ $(\mathrm{OH})_{2}$ による緻密化の効果のためと考えられる. $20 \%$ 溶液の場合は, $\mathrm{CaCl}_{2}$ 溶液の場合よりも劣化はさらに小 さい．これは表層部の緻密化と空隙水の凍結温度の低下 によると考えられる。

Fig. 8 に $\mathrm{CaCl}_{2}$ 溶液の場合の溶液濃度とスケーリング 量の関係を示す. Non AEでは $5 \%$ 前後に劣化が最大

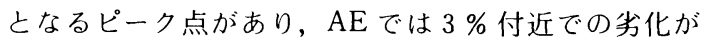
最大となった。また，図示していないが $\mathrm{MgCl}_{2}$ 溶液の 場合の $\mathrm{AE}$ では, $\mathrm{CaCl}_{2}$ 溶液の場合と同様, $3 \%$ 付近で 最大劣化のピークを示した. $\mathrm{CaCl}_{2}$ 溶液の場合は劣化 ピークの濃度より大きくなるに従って, 劣化は急激に低 減するのに対して, $\mathrm{MgCl}_{2}$ 溶液の場合は, 12 cyc. $\sim 24$ cyc. では $6 \%$ と $10 \%$ の劣化の差異がない.

以上の結果より, $\mathrm{CaCl}_{2}, \mathrm{MgCl}_{2}$ 溶液とも $\mathrm{AE}$ の場合 は $3 \%$ 程度より低い濃度において, また $\mathrm{CaCl}_{2}$ 溶液の

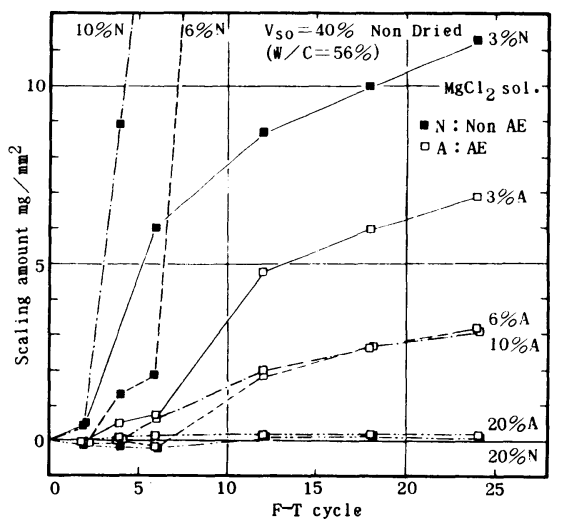

Fig. 7 F-T cycle $\sim$ scaling amount relationship (concentration of $\mathrm{MgCl}_{2}$ sol.). 


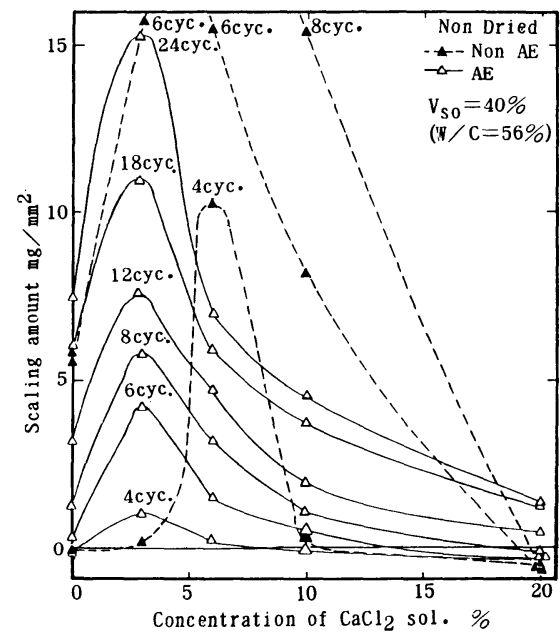

Fig. 8 Concentration $\sim$ scaling amount relationship $\left(\mathrm{CaCl}_{2}\right.$ sol. $)$.

Non AE では $5 \sim 6 \%$ 程度の濃度において硬化セメント ペーストのスケーリング劣化が最も著しいことが判明し た。なお、コンクリートに関する Verbeck らの研究"1に よれば, $\mathrm{NaCl}, \mathrm{CaCl}_{2}$ 溶液ともに, $2 \sim 4 \%$ 濃度におい てスケーリング劣化が最大となっている。このように $3 \%$ 程度以下の比較的低濃度において, スケーリング 劣化が最大となるのは,濃度が低いほど凍結温度も高く, したがって凍結水量も多いこと, 濃度の高い場合のよう に凍結融解サイクルの進行に伴って空隙を充填する新生 成物も少ないため飽水度の上昇が継続すること, などの ためと考えられる.

\section{5. スケーリング劣化に及ぼす乾燥の影響}

\section{（1）エントレインドエアーの影靇}

Fig. 9(a) に示すように，乾燥しない場合で初期固相 率が適度に大きいときは，スケーリング少化に対してエ
ントレインドエアーの効果があり, 初期固相率が小さい 場合あるいは初期固相率が大きくても塩溶液などで飽水 度が高い場合は, $\mathrm{AE}$ 荗混入は耐劣化上からは逆効果と なること ${ }^{111.12}$ が知られている。これに対して乾燥した場 合 (Fig.9(b)) は, AEではNon AEに比較して耐劣 化性能が著しく向上している. 特に初期固相率 $35 \%$ で $\mathrm{AE}$ の場合, 乾燥なしでは凍結融解過程の初期段階で著 しい劣化を生じ，しかもその劣化はNon AEょりも大 きく, $\mathrm{AE}$ 剂混入が耐劣化上からは逆効果となっている. しかし, 乾燥した場合では, 2 cyc. ですでに最大飽水度 に達し、これが $12 \mathrm{cyc}$. まで持続し，以後 $36 \mathrm{cyc}$. まで 緩慢ながらわずかに劣化の兆をみせているが，全体とし てはきわめて健全である．飽水度が上昇するにもかかわ らず劣化が進行しないこのような挙動は, 乾燥しない場 合 (Fig.9(a)) にはAEであっても飽水度の増大ととも に急激に劣化が進行するの之は，きわめて対照的である. このような乾燥による耐スケーリング劣化の向上は，コ ンクリートの場合にもみられる11,71,131.

Non $\mathrm{AE}$ の場合の表層は, $\mathrm{Mg}(\mathrm{OH})_{2}$ および $\mathrm{CaCO}_{3}$ の多い緻密層が, $30 \sim 40 \mu \mathrm{m}$ 程度形成されている. しか し，その直下は乾燥しない場合より粒状化は少ないが， きわめて多孔化している。一方, $\mathrm{AE}$ の初期固相率 40 \%では, 表面付近の緻密層は $100 \mu \mathrm{m}$ 程度あり, さらに 直下にはやや多孔的ではあるが，Photo7(a) に示すよ うに，大型空隙を充填するように新たな生成物がみられ る.さらに，エントレインドエアー内にも同様の物質が 生成している. 空隙率の大きい初期固相率 $35 \%$ の場合 には，表層に厚さ $50 \mu \mathrm{m}$ 程度および表面から $0.5 \mathrm{~mm}$ の位置に厚さ約 $150 \mu \mathrm{m} の \mathrm{Mg}(\mathrm{OH})_{2}, \mathrm{CaCO}_{3}$ および $\mathrm{CSH}$ の固溶した緻密層が生成（Photo8(a)）している. 表層緻密部の直下にある多孔部は, 新たに生成した物質 で充填されており，中間部の空隙中にも新たな生成物が 観察され，さらにエントレインドエアーの内側に生成物 がみられ，気泡款が肥厚し緻密になっている

(Photo 8(c)) のが観察される.

乾燥後の塩溶液浸漬により生じた生成物は, $\mathrm{EDX}$ 分析 (Photo 7 (b), 8(b)) より, 乾燥時 $に \mathrm{Ca}(\mathrm{OH})_{2}+\mathrm{CO}_{2} \rightarrow \mathrm{CaCO}_{3}+\mathrm{H}_{2} \mathrm{O}$ 上り生成し た $\mathrm{CaCO}_{3}$ および $\mathrm{Ca}(\mathrm{OH})_{2}+\mathrm{MgCl}_{2} \rightarrow \mathrm{Mg}(\mathrm{OH})_{2}$ $+\mathrm{CaCl}_{2}$ より生成した $\mathrm{Mg}(\mathrm{OH})_{2}$ と $\mathrm{CSH}$ が固 溶した状態になっていると考えられる. 乾燥し た場合, CSH 自体の組織が緻密化すること ${ }^{14)}$, $\mathrm{CaCO}_{3}$ を生成すると同時に炭酸化収縮のため 組織が緻密化すること ${ }^{15}$, 空隙が生成物によっ て充填され空隙率が低下すること敫さらに $\mathrm{AE}$ ではエントレインドエアーの気泡殼が充実し $\mathrm{AE}$ 効果が十分に発揮されること, などの理由

Fig. 9 F-T cycle $\sim$ scaling amount relationship (effect of drying). 


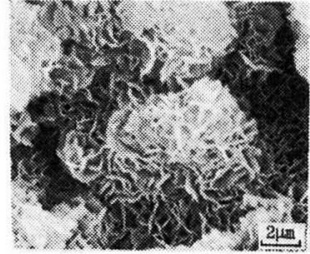

(a) Compound in cavity

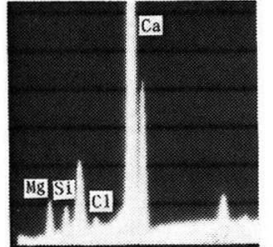

(b) EDXA spectrum of the compound
Photo 7 Cavity filled up with compound at surface portion ( $V_{s 0}=40 \%, \mathrm{MgCl}_{2} 3 \%$ sol. ).

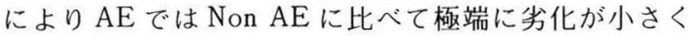
なるものと考えられる。ささらに, $\mathrm{MgCl}_{2}$ 溶液浸漬では $\mathrm{Mg}(\mathrm{OH})_{2}$ の生成により, 真水中の場合よりも劣化が小 くなる. 特に初期固相率の小さい $35 \%$ の $\mathrm{AE}$ の場合に は，表面付近に生成する二重の緻密層のため, $\mathrm{Cl}^{-}$イ才 ンの浸入 ${ }^{17}$ および飽水度の上昇が抑制されるため, Non $\mathrm{AE}$ に比較して著しく劣化が小さくなるものと考えられ る.

\section{（2）塩溶液の種類による相違}

Fig. 10 に示すように, AE の場合は 24 cyc.において も質量が初期值より大きい状態にありスケーリングの進 行は著しく小さい。一方, Non $\mathrm{AE}$ では $\mathrm{MgCl}_{2}$ 溶液浸 漬の場合の劣化が大きく, 次いで $\mathrm{NaCl}, \mathrm{CaCl}_{2}$ の溶 液浸漬の場合であり，海水浸漬がこれに続いている. Non AE の塩溶液の場合は, 初期には吸水状態であるが, スケーリングの開始と同時にほぼ一定割合で劣化が進行 する．これらの劣化の勾配は，乾燥なしの場合（Fig. 3) の $\mathrm{NaCl}, \mathrm{CaCl}_{2}$ 溶液, 海水浸漬の場合より小さいが, 乾燥した場合, $\mathrm{MgCl}_{2}$ 溶液浸漬では, 乾燥なしの場合 にみられた凍結融解回数の増加に伴う劣化の低減はなく むしろ劣化が最も大きい.

$\mathrm{MgCl}_{2}$ 溶液浸漬の Non $\mathrm{AE}$ の場合, 表層緻密部直下 の微構造は多孔化している.これに対してほとんど劣化 を生じない $\mathrm{NaCl}, \mathrm{CaCl}_{2}$ 溶液および 海水浸漬の場合の $\mathrm{AE}$ では，表層部の空隙に新たな生成物が空隙を充填す るように生じている，すなわち， $\mathrm{NaCl}$ 溶液浸漬の場合 は, 表層部 $1 \mathrm{~mm}$ 付近の空隙が粒状の生成物（Photo 9 (a)）によって充填されているのが観察された.この物

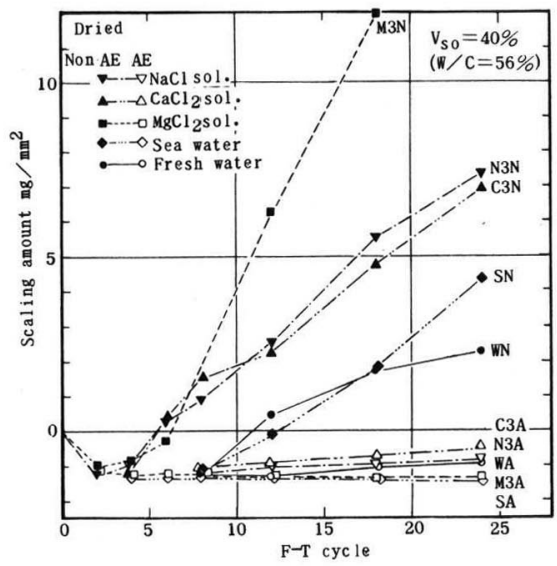

Fig. 10 F-T cycle $\sim$ scaling amount relationship (difference among chlorides).

質は $\mathrm{Ca}, 86.7 \%$ を主成分とし，少量の $\mathrm{Si} ， 9.3 \%$ お よび $\mathrm{Cl}, 1.4 \%$ を含む (Fig. 9(b)). また， $6 \sim 8 \mathrm{~mm}$ 付 近および $\mathrm{AE}$ 気泡中には生成物が空隙内に密生してお り，その主成分元素は， $\mathrm{Ca}, 97.0 \%$ に微量の $\mathrm{Si}, 0.4$ \%および $\mathrm{Cl} ， 2.25 \%$ を含んでいる. 表層の生成物は $\mathrm{CaCO}_{3}$ と $\mathrm{CSH}$ の固溶体であり, 内部の生成物は $\mathrm{Ca}$ $(\mathrm{OH})_{2}+\mathrm{CaCO}_{3}+\mathrm{CSH}$ と考えられる.

$\mathrm{CaCl}_{2}$ 溶液浸漬の場合は, 表層部の空隙中に Photo 10（a）に示すように生成物を生じ空隙を充填している. この生成物の主成分は $\mathrm{Ca}, 73.2 \%$ と $\mathrm{Si}, 18.5 \%$ で, これに $\mathrm{Cl}, 2.6 \%$ が含まれている. したがって $\mathrm{CaCO}_{3}$ と $\mathrm{CSH}$ の固溶体と判断される. 内部 $(6 \sim 8 \mathrm{~mm})$ の空 隙には瀻維状および大型粒状の生成物が生じており，そ の成分元素 (Photo 10(b)) は, ほぼ等しくそれぞれ Ca, $83.1 \%, \mathrm{Si}, 7.4 \%, \mathrm{Cl}, 4.7 \%$ および Ca, $85.9 \%, \mathrm{Si}$, $5.6 \%, \mathrm{Cl}, 4.3 \%$ であり，いずれも $\mathrm{Al}, \mathrm{Fe}$ は検出さ れない，以上の結果から両者は同一成分を有する生成物 $\left(\mathrm{Ca}(\mathrm{OH})_{2}+\mathrm{CaCO}_{3}+\mathrm{CSH}\right)$ であり, 繊維状から粒状 生成物へと成長して空隙を充填するものと考えられる.

海水浸漬の場合は, Photo11（a）に示すように，表面 の $\mathrm{Mg}(\mathrm{OH})_{2}$ および $\mathrm{CaCO}_{3}$ からなる緻密層の直下から $1 \mathrm{~mm}$ 付近には, 空隙を充填するように大小の粒状物質 が生成している，この生成物は $\mathrm{Mg}, \mathrm{Si}, \mathrm{Cl}, \mathrm{Ca}$ から

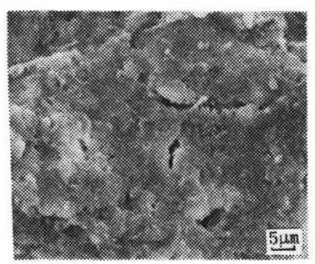

(a) Dense layer at around $0.5 \mathrm{~mm}$ from surface

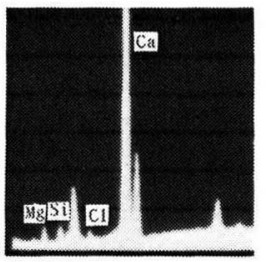

(b) EDXA spectrum of the dense layer

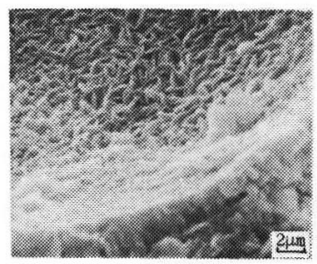

(c) Air void shell filled up with new compound

Photo 8 Dense layer and air void shell at surface portion ( $V_{s 0}=35 \%, \mathrm{MgCl}_{2} 3 \%$ sol. ). 
(a) Compound filling up cavities at surface portion

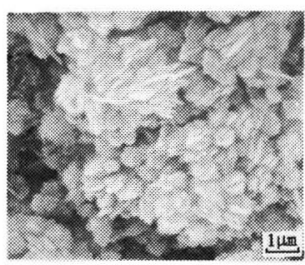

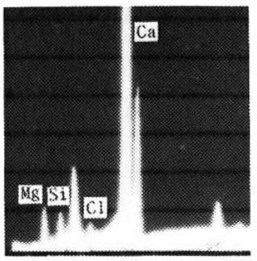

(b) EDXA spectrum of the compound
Photo $9 \mathrm{NaCl} 3 \%$ solution.

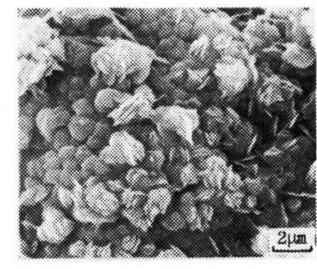

(a) Compound filling up cavities at surface portion

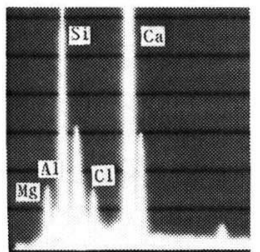

(b) EDXA spectrum of the compound
Photo $10 \mathrm{CaCl}_{2} 3 \%$ solution.

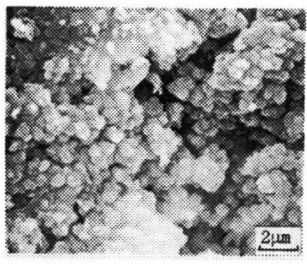

(a) Compound filling up cavities at surface portion

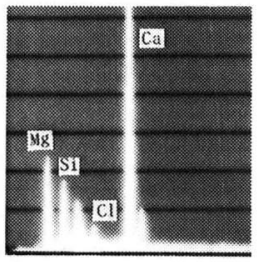

(b) EDXA spectrum of the compound
Photo 11 Sea water

構成 (Photo11(b)) され，その割合はそれぞれ 16.9, 12.1, 2.6 および $68.3 \%$ であり, $\mathrm{Ca}(\mathrm{OH})_{2}+\mathrm{CaCO}_{3}+$ $\mathrm{Mg}(\mathrm{OH})_{2}+\mathrm{CSH}$ と考えられる. また, 内部 $(6 \sim 8 \mathrm{~mm})$ には，新たな生成物が全体的に観察された。主な成分元 素は, $\mathrm{Ca}, 96.2 \%$ で，その他に $\mathrm{Si}, 2.1 \%, \mathrm{Cl}, 1.0$ \% および $\mathrm{Mg}, 0.7 \%$ を含むが， $\mathrm{Al}, \mathrm{Fe}$ が検出されな いことからこの生成物は $\mathrm{CaCO}_{3}$ と考えられる.

以上の $\mathrm{NaCl}, \mathrm{CaCl}_{2}$ 溶液および海水浸漬の場合, 表 層部における生成物の方が $\mathrm{Ca}$ 量が少なく $\mathrm{Cl}$ 量の多い 元素組成であり, $\mathrm{NaCl}, \mathrm{CaCl}_{2}$ 溶液, 海水浸漬の順に この傾向は強い.

\section{（３）塩溶液の濃度による相違}

Fig. 11 に凍結融解回数とスケーリング量の関係を示 す. Non $\mathrm{AE}$ の濃度 $3,6,10 \%$ の場合, それぞれ $4,2,6$ cyc. までの吸水過程を経た後，急激に劣化した。Non $\mathrm{AE}$ の $20 \%$ および $\mathrm{AE}$ の 3,6,10\% は, 24 cyc. までで ほとんどスケーリング劣化を生じない，AEの $20 \%$ の 場合の表層部から $10 \mathrm{~mm}$ 程度までの微構造は, 深さ約 $1 \mathrm{~mm}$ までやや多孔的であるが, その直下はきわめて緻

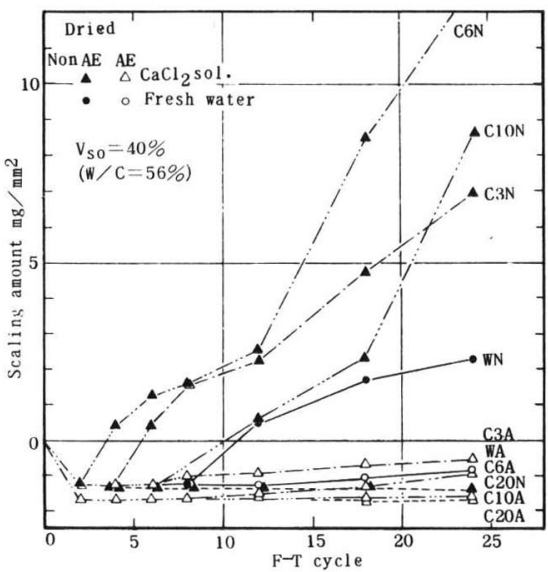

Fig. 11 F-T cycle $\sim$ scaling amount relationship (difference due to concentration of $\mathrm{CaCl}_{2}$ sol.).

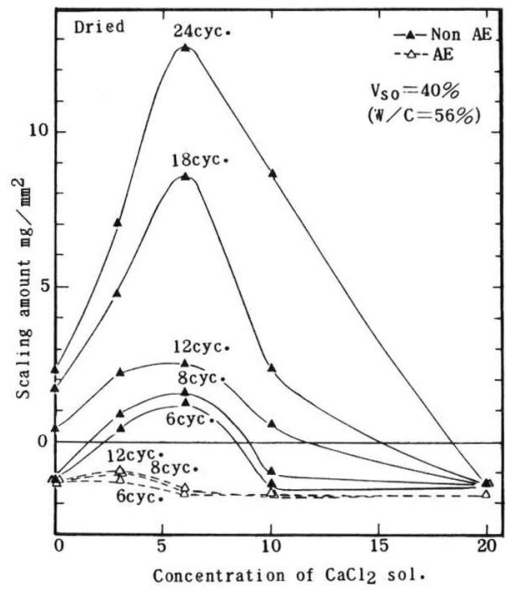

Fig. 12 Concentration $\sim$ scaling amount relationship ( $\mathrm{CaCl}_{2}$ sol. ).

密な形態を示し，続いて 8〜10 $\mathrm{mm}$ まで空隙を埋めるよ うに生成物が生じている. $1 \mathrm{~mm}$ 付近の緻密部の成分元 素は $\mathrm{Ca}, 72.0, \mathrm{Cl}, 14.0, \mathrm{Si}, 10.2 \%$ であり, $\mathrm{Cl}$ の 多いのが特徴的である.また, 空隙には粒状結晶が観察 されるが，この成分元素は， $\mathrm{Ca}, 73.7, \mathrm{Cl}, 25.5, \mathrm{Si}$, $0.8 \%$ で主に $\mathrm{Ca} と \mathrm{Cl}$ から構成されている。これらの 生成物は前述の XRD の結果をも考虑して, $\mathrm{CaCl}_{2} \cdot \mathrm{Ca}$ $(\mathrm{OH})_{2} \cdot \mathrm{H}_{2} \mathrm{O}, \mathrm{Ca}(\mathrm{OH})_{2}$ および $\mathrm{CaCO}_{3}$ の固溶体と考え られる。

$\mathrm{CaCl}_{2}$ 溶液濃度とスケーリング量の関係を, Fig. 12 に示す. AE の場合はスケーリング劣化をほとんど生じ ないため,濃度の影響を厳密に論ずることはできないが， 吸水状態のままでのわずかなスケーリング劣化から判断 すれば, 劣化のピークは約 $3 \%$ 程度の濃度にあると推 測される. Non AEの場合は，明らかに $6 \%$ 付近に劣

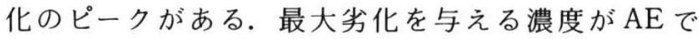


$3 \%$, Non AE で $6 \%$ という結果は, 乾燥しない場合 の $\mathrm{CaCl}_{2}, \mathrm{MgCl}_{2}$ 溶液の $\mathrm{AE}$ および $\mathrm{CaCl}_{2}$ 溶液の Non $\mathrm{AE}$ (Fig. 8) に等しい.

\section{6. まと め}

塩溶液の種類および濃度が硬化セメントペーストの凍 結融解作用によるスケーリング劣化に与える影響を, 微 構造変化との関連において検討した。この結果，スケー リング劣化が塩化物の種類によって著しく相違すること および塩溶液の濃度には最大のスケーリング劣化を与え る值のあることが判明した。また，スケーリング劣化に 及ぼす前処理乾燥の影響についても検討し，乾燥による スケーリング劣化の低减効果が, 新たな生成物による微 構造の変化に起因することを明らかにした。本研究の結 果を要約すると次のようである.

（1）海水以外の壏溶液浸漬の場合, フリーデル塩の 生成は，凍結融解回数の増加に伴って増大する傾向にあ り，内部よりも表層部において多い。海水浸漬の場合は， 凍結融解回数の増加に伴ってエトリンガイトを二次生成 する.

(2) $\mathrm{CaCl}_{2}$ 溶液浸漬では，同一濃度でも $\mathrm{Ca}(\mathrm{OH})_{2}$ およびフリーデル塩の生成は表層部之内部で相当に異な り，溶液濃度によって生成物に相違がある。

（3）溶液の種類による劣化の相違は，スケーリング 劣化の大きい方から, Non $\mathrm{AE}$ では $\mathrm{NaCl}, \mathrm{CaCl}_{2}$ 溶液, 海水, $\mathrm{MgCl}_{2}$ 溶液, 真水, $\mathrm{AE}$ では $\mathrm{NaCl}, \mathrm{CaCl}_{2}$, $\mathrm{MgCl}_{2}$ 溶液, 海水, 真水の順であり, $\mathrm{NaCl}$ おょび $\mathrm{CaCl}_{2}$ 溶液では, $\mathrm{AE}$ とした場合でも劣化が大きい傾向 があり，また海水では $\mathrm{AE}$ の効果が著しい.

(4) 劣化の激しい Non $\mathrm{AE}$ の $\mathrm{NaCl}, \mathrm{CaCl}_{2} 3 \%$ 溶 液および海水浸漬の場合の微構造は, $\mathrm{Ca}(\mathrm{OH})_{2}$ が溶解 しあるいは層状剥離を生じて損傷し，また表層部では $\mathrm{CSH}$ （I）が分離し，内部では CSH（III）が崩壊また は粒状分離している。

（5）凍結融解回数に伴って劣化が緩慢となる $\mathrm{AE}$ の海水, $\mathrm{CaCl}_{2}$ 溶液および Non $\mathrm{AE}$ の $\mathrm{MgCl}_{2}$ 溶液の場 合には，表層 $1 \mathrm{~mm}$ 程度付近までは緻密層を形成し， その直下は著しく多孔化している．この緻密層は $\mathrm{CaCl}_{2}$ 溶液の場合は $\mathrm{Ca}$ の多い生成物であり, $\mathrm{MgCl}_{2}$ 溶液の場 合は $\mathrm{Mg}(\mathrm{OH})_{2}$ を主成分亡する生成物である。

（6） $\mathrm{AE}$ の場合, $\mathrm{CaCl}_{2}, \mathrm{MgCl}_{2}$ 溶液では濃度 $3 \%$

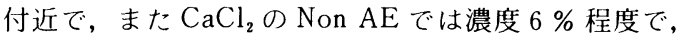
スケーリング劣化が最大となる。この傾向は前処理乾燥 した場合でも同様である.

（7）前処理乾燥した場合， $\mathrm{AE}$ の場合は塩溶液の種 類に無関係に $24 \mathrm{cyc}$.までほとんど劣化しない。これは 生成物による表層部の緻密化，多孔部の充填による大型
空隙の減少およびエントレインドエアーの気泡殸の充実 なゼ，微構造の変化が主な要因である.

1) Verbeck, G. J. and Klieger, P. : Studies of "salt" scaling of concrete, Highway Research Board, Bulletin No. 150, pp. 1 13, 1957.

2) Hartmann, E. : Über die Wirkung von Frost und Tausalzen auf Beton ohne und mit Luftporenbildenden Zusatzmitteln, Zement-Kalk-Gips, 10 Jahrgang, Heft 7, S. 265 323, Juli, 1957.

3) Cordon, W.A. : Freezing and thawing of concretemechanism and control, ACI Monograph No. 3, 1966.

4) Browne, F. P. and Cady, P. D. : Deicer scaling mechanisms in concrete, ACI SP 47, pp. 101 119, 1975.

5）前川静男・今井益隆：養生程度がコンクリートの耐久性 に与える影響, セメントコンクリート, No. 345, pp. 22 一 29, 1975 年 11 月。

6）佐伯 舁・兴井 宏・鮎田耕一：夏期に暴露されたコン クリートの表面剝離耐力に関する 2,3 の実験，七メント 技術年報, No. 34, pp. 345 348, 1980 年.

7）佐伯 昇・高田宣之・藤田嘉夫：コンクリート表面部の 劣化についての 2, 3 の実験, 第 2 回コンクリート工学年 次講演会講演論文集, pp. 345 348, 1980 年.

8) Hochstetter, R. : The pore structure of some building materials and their resistance against the combined attack of frost and salt solutions, Int. Symposium RILEM/ IUPAC, No. 6, F 51 F 66, 1973.

9) Kayyali, O.A., Page, C. L. and Ritchie, A. G. B. : Frost action on immature paste-microstructural features, J. ACI, Vol.77, No. 4, pp. 264 268, July-August, 1980.

10）藤井 卓・藤田嘉夫：硬化セメントペーストの凍結融解 劣化に及ぼす塩化物の影響, 上木学会論文報告集, No. 343,pp. 209 217, 1984 年 3 月.

11) Litvan, G. G. : Phase Transitions of Adsorbates: VI, Effect of deicing agents on the freezing of cement paste, J. American Ceramic Society, Vol. 58, No. $1 \sim 2$, pp. 26 $\sim 30,1975$.

12）藤井 卓：塩化物の作用をうけるセメントペーストの凍 結融解劣化，七メント技術年報，No. 36, pp. 345 348, 1982 年.

13）鮎田耕一・林 正道：微小モルタル供試体の強度に及ぼ す炭酸化の影響, 第 3 回コンクリート工学年次講演会講 演論文集, pp. 105 108, 1981 年.

14) Grudemo, A. : Microcracks, fracture mechanism, and strength of the cement paste matrix, Cement and Concrete Research, Vol.9, No. 1, pp. 19 34, 1979.

15) Ramachandran, V.S., Feldman, R.F. and Beaudoin, J. J. : CONCRETE SCIENCE, Heyden, pp. 380 386, 1981.

16) Mehta, P.K. : Durability of concrete in marine environment--a review, ACI SP 65, pp. 1 20, 1980.

17) Conjeaud, M.L. : Mechanism of sea water attack on cement mortar, ACI SP 65, pp. 39 61, 1980.

(1985.1.14 • 受付) 